\title{
PÅ TYSKE PRAMISSER, MEN MED GLOBALT PERSPEKTIV OVERVÅGNING I NYERE TYSK LITTERATUR
}

Overvågning og angiveri er følsomme temaer i den offentlige bevidsthed i Tyskland. Alene i kalenderåret 2009 har tysk presse oprullet store overvågningsskandaler i Deutsche Bahn, Deutsche Telekom og Deutsche Bank, skandaler, der har ført til direktørers afgang og enorme prestigetab for de berørte firmaer. Pressen har også afsløret, at apoteker stiller oplysninger om medicinbrug til rådighed for arbejdsgivere, og vist, hvordan store indkøbskæder systematisk overvåger de ansatte. En stor tysk avis som Frankfurter Rundschau har ligefrem her i foråret 2010 en rubrik på sin hjemmeside, der hedder "Überwacht" (overvåget), det venstreorienterede tageszeitung en tilsvarende "Schwerpunkt Überwachung" (hovedtema overvågning). Begge fyldes regelmæssigt med nyt stof.

Det er svært at sige, om overvågningen er større i Tyskland end i andre sammenlignelige lande, men opmærksomheden over for temaet er tydeligvis massiv. Hen over vinteren 2009-2010 anklagede ikke mindre end 35.000 borgere den tyske stat ved Forbundsdomstolen i Karlsruhe i forbindelse med implementeringen af EU's bestemmelser om dataopbevaring. Den 3. marts gav Forbundsdomstolen de klagende ret: Forbundsdomstolen må revidere implementeringen, landets højeste domstol mener, regeringen er gået for vidt. Pressedækningen og diskussionen af disse sager har været omfattende i alle Tysklands store medier. Overvågning er hot stuff i Tyskland.

Det er let at se, at denne optagethed er et resultat af tysk historie. Den nazistiske politistat blev i den østlige del af Tyskland afløst af den kommunistiske (DDR), men spaltningen af landet førte også til en massiv overvågning af oppositionelle grupper i Forbundsrepublikken og til en generel mistænksomhed borgerne imellem. Da Tyskland efter murens fald blev forenet og skulle til at starte "på en frisk", var det en af de vigtigste målsætninger at få ryddet denne mistænksomhed af vejen. Det var bl.a. baggrunden for den hurtige lukken op for Stasi-arkiverne efter murens fald. En østrigsk hjemmeside, "Überwachungsstaat - Nein Danke” (overvågningsstat nej, tak), der også holder systematisk øje med debatten i Forbundsrepublikken, refererer uafbrudt til DDR for eksempler på forhold, man skal undgå. "Aldrig mere Stasi”, synes motto'et at være for en politisk bevægelse, som eksplicit opfatter sig som arvtager fra den østtyske borgerretsbevægelse, der i dag figurerer som sidste del af "Die Grünen/Bündnis 90". At Forbundsdomstolen i Karlsruhe også ser sig 
som forvalter af disse idealer - ofte i domme mod regeringen selv - er selvfølgelig interessant og håbefuldt for det demokrati, som omverdenen også i nyere tid har været skeptisk over for. ${ }^{1}$

Derfor er det påfaldende, at overvågningstemaet aldrig har spillet nogen fremtrædende rolle i den nye tyske litteratur. At det ikke kunne det i DDR, er indlysende. Det vender jeg tilbage til. Men heller ikke forfatterne i Forbundsrepublikken før 1989 interesserede sig alvorligt for temaet, hvad Franz Huberth i sin artikel "Die Stasi in der deutschen Literatur" tolker som udtryk for "venstreorienteret blindhed, desinteresse, politisk hensynstagen eller skyhed" - det var ikke, fordi man ikke vidste, hvad der foregik. ${ }^{2}$ Siden murens fald og genforeningen i 1990 er der fremkommet en uoverskuelig mængde af erindringer, forskningsresultater og features om livet i DDR, herunder også om Stasis virksomhed i forhold til forfattere og andre kunstnere. En stor del af debatten om dette forhold har fundet sted i forbindelse med spektakulære sager om prominente forfatteres involvering med det hemmelige politi: Heiner Müller, Monika Maron og ikke mindst Christa Wolf, hvis roman Hvad blev tilbage i 1993 udløste den såkaldte "store, tyske forfatterstrid". Men forskerteamet omkring Franz Huberth konkluderede i 2003, at temaet stadig ikke synes at have frembragt væsentlige skønlitterære værker. De få eksempler, Huberth nævner, ${ }^{3}$ benytter temaet "som en formodet garant for autenticitet, voyeurisme og spænding” (27). Værker med større æstetisk ambition og kvalitet er det ikke.

Måske er denne tilstand dog aktuelt ved at ændre sig. Det kan hænge sammen med, at den "klassiske" DDR-litteratur fra 1960 og frem til murens fald i disse år oplever en bemærkelsesværdig renæssance i den tyske offentlighed, med genudgivelser, seminarer og monografier til følge. Under den ironiske titel "Im Osten ging die Sonne auf” analyserede Alexander Cammann i Die Zeit i november 2009 elementerne i denne renæssance. Han så den som et resultat af, at man med de mange års afstand havde kunnet nylæse denne litteratur og mere uhildet se dens kvaliteter kombineret med en fascination af den rolle, litteratur havde spillet i det østtyske diktatur. Den etiske forpligtethed og eksisistentielle alvor, som litteratur havde i et samfund uden andre egentlige offentlighedsformer, kunne godt gøre forfattere, der var ved at drukne i mediesamfundets mange udbud, misundelige. Og de østtyske forfatteres evne til at finde hullerne i diktaturet og på trods af censur og forfølgelse alligevel skildre de virkelige problemer, vækker stadig beundring. Cammann er dog

1 I sin bog Tyskland - Europas hjerte fra 2009 (Gyldendal, Kbh.) konkluderer Per Øhrgaard en gennemgang af Forbundsdomstolens virke således: "Der er altså noget ikke bare ved siden af, men også over forbundsdagen, hvilket i moderne klædebon viderefører en tysk tradition for at sætte retsstaten over det politiske demokrati. I en tid med svigtende demokratisk legitimation og tiltagende stemningspopulisme er det måske ikke det dårligste forsvar for demokratiet at have en sådan domstol”: 92. Man kan sammenligne den progressive tyske Forbundsdomstol med den konvervative amerikanske højesteret og se forskellen.

2 Huberts disputats Aufklärung zwischen den Zeilen. Stasi als Thema in der Literatur, Köln: Böhlau Verlag 2003 er stadig den mest omfattende gennemgang af temaet. Værket rummer ikke mindst en række tætte analyser af skønlitterære behandlinger af Stasi efter murens fald.

3 Hans Joachim Schädlichs Trivialroman, Jürgen Fuchs Magdalena og Erich Loests Nikolaikirche, alle skrevet af tidligere DDR-forfattere. 
også opmærksom på bagsiden ved denne interesse, der også gælder, hvad han kalder samme litteraturs "nicheborgerlighed og kunstneriske traditionsbevidsthed" (13).

Dobbeltheden vender vi tilbage til; men jeg betragter den af Cammann beskrevne renæssance for DDR-litteraturen som en vigtig forudsætning for ny tysk litteraturs behandling af overvågningstemaet. Lad os da se lidt nærmere på denne forudsætning.

Som udgangspunkt måtte man regne med, at intet værk udkom, intet billede blev udstillet i et land som DDR, uden at en eller anden parti- eller politiinstans havde godkendt det. Allerede inden muren faldt, var den østtyske forfatter Joachim Walther (f. 1943) gået i gang med at samle stof om det hemmelige politi, Stasis, overvågning af den østtyske litteratur, og da de Stasi-arkiver, som man ikke havde nået at tilintetgøre i de hektiske dage i efteråret 1989, blev åbnet for offentligheden, kunne han uddybe og fuldføre sine studier. Det resulterede i 1996 i kæmpeværket Sicherungsbereich Literatur. Schriftsteller und Staatssicherheit in der Deutschen Demokratischen Republik, der ikke siden er overgået i omfang og grundighed. Siden 2001 har Walther i øvrigt sammen med Ines Geipel ledet projektet "Archiv unterdrückter Literatur in der DDR" under "Die Bundesstiftung zur Aufarbeitung der SED-Diktatur" i Berlin ${ }^{4}$. Styrken i Walthers studie ligger i påvisningen af Stasi-apparatets finmaskethed, der i virkeligheden reducerede de egentlige censurinstansers betydning. Forfatterforbundet, forlagene, Pen, litteraturtidsskifterne og anmelderkorpset, Akademie der Künste og en lang række kulturelle formidlingsinstitutioner var alle gennemsyret af meddelere til Stasi, der gennem DDRs historie sørgede for, at der altid kørte en eller anden 'sag' mod en forfatter, en sag, der ofte betød fængsling eller udvisning. Derigennem opnåede man den vigtigste af censurprocesserne: selvcensuren, der naturligvis var den mest omkostningsfrie for Stasi. Det er bl.a. omfanget af denne selvcensur, "Arkivet for den undertrykte litteratur i DDR” er ved at undersøge.

DDR adskilte sig fra det øvrige Østeuropa ved at have en stat, som man var historisk forbundet med, og hvor der taltes det samme sprog, lige på den anden side af grænsen, en stat, der holdt øje med, hvad der foregik i landet. Muren var porøs, og materialer og informationer sivede uafbrudt gennem den, og det østtyske magtapparat var tiltagende følsomt over for de vesttyske anskrig, når undertrykkelsen blev for massiv i DDR. Stasi bevægede sig i alle årene i en balancegang mellem for meget og for lidt, og Joachim Walther beskriver en mængde groteske eksempler på magtapparatets problemer. Også Walthers gennemgang af enkelte Stasi-agenters personlige historier og hans analyser af Stasi-sproget fører ofte den saglige diskurs hen i retning af det groteske: selv om kampen om ytringsfriheden var blodig alvor for mange forfattere i DDR, havde den også et komisk skær over sig. Der var et åbenlyst

4 Siden 2005 har dette projekt bl.a. udgivet "Die verschwiegene Bibliothek" (det fortiede bibliotek) bestående af værker, der strandede i den østtyske censur, og ikke efter murens fald har kunnet finde et forlag. Biblioteket rummer foreløbigt 10 bind. 
misforhold mellem den betydning, Stasi tillagde litteraturen, og den virkning, den ville have haft, hvis den havde kunnet udfolde sig frit. I virkeligheden nød forfatterne i DDR fordel af denne overvurdering, der gav dem en status, der ofte langt overgik de litterære kvaliteter i de værker, de skrev. For mange DDR-forfattere betød nedgangen i status efter murens fald et chok, som de aldrig er kommet sig over.

Men selv om Stasis net over litteraturen var finmasket, var der huller i det, hvad Walther også giver adskillige eksempler på i sin bog. Rundt omkring $\mathrm{i}$ apparatet sad folk, der tog chancer, og lod bøger passere, som de vidste, Stasi ikke tolererede, bl.a. når det gjaldt omtalen af det hemmelige politi selv, hvilket var noget af det absolut forbudte i DDR. Man satsede også sommetider på, at publikum var bedre til at læse end Stasi. Mange af de folk, som Stasi fik anbragt i kulturlivet, havde ikke nogen relevant uddannelse eller særlig megen forstand på kunst, påviser Walther. Til gengæld udviklede læsere i DDR ofte en fantastisk evne til at læse underforståede koder og slørede budskaber. F.eks i historiske romaner, der var en i forhold til litteraturen $i$ andre europæiske lande monstrøst udbredt genre. Ikke siden 1600-tallet havde så mange romaner og teaterstykker foregået i det antikke Grækenland som i DDR. En af de vigtigste var Christa Wolfs Kassandra fra 1974 med en tydelig Stasi-figur. Østtyskerne var velbevandrede i historien.

Et problem for Stasi var, at spioneri og angiveri grundlæggende foregår efter det samme mønster i alle samfund. Det var en del af den officielle østtyske historieopfattelse, at man kritiserede feudalismen og kapitalismen, og så socialismen som et opgør med disse samfundsformationer. Men beskrev man stikkervirksomhed i tidligere perioder, kunne den østtyske læser let se, at ikke meget havde forandret sig i DDR. En af de mest udbredte vitser i DDR lød: hvad er forskellen mellem kapitalisme og socialisme? Jo, under kapitalismen udbytter mennesket mennesket, under socialismen er det omvendt. Mange historiske romaner i DDR blev læst med denne optik.

Et eksempel er Joachim Walthers egen roman fra 1982 Bewerbung bei Hofe (Ansogning til hoffet), der indeholder et portræt af en Stasi-agent, som man ellers skulle have troet umulig i DDR. Handlingen er henlagt til August den Stærkes hof i Dresden i begyndelsen af 1700-tallet og indeholder en fantastisk skildring af en agent, Délateur, med alt hvad dertil hører: fra overvågning $i$ alle aspekter, opsnapning af breve, bearbejdning af venner, bestikkelse og intrigering, etc. frem til fængsling og udvisning af en ung digter. I en vanvittig og grotesk passage udvikler Délateur en 'utopi' (som han kalder det) om det totale overvågningssamfund, hvor alle spionerer mod alle, og hvor en generel skyldsbevidsthed fører til, at alle altid straffer den mindst forseelse hos sig selv. Politi er overflødigt, alle hjem er straffeanstalter, regeringen opløser sig selv (65). En fed parodi på de forestillinger om det kommunistiske samfund, som stadig var officiel ideologi i DDR.

Det afgørende i portrættet af Délateur, der altså fik lov at udkomme på det lille Berlin-forlag Neues Leben (som oven i købet genudsendte Ansøgning til hoffet i 1984), er denne komiske dimension: f.eks i en scene, hvor Délateur i en samtale med bogens fortæller, der er ceremonimester ved hoffet, taler sig frem til en sentimental sympati 
for sit offer. Det er grinagtigt sentimentalt. I romanen som i forskningsværket består Walthers underbinding af Stasis magt i en indføling i overvågningsapparatet og en indefra påvisning af dets menneskelige og intellektuelle elendighed. Offeret, en ung digter ved navn Günther, er på mange måder en fusentast, ferm til at skrive vers, og tilhænger af oplysningsfilosofien, men uden større moral og øjensynlig uden talent (de digte, Walther lader ham fremsige, er komisk dårlige). Det er overvågningen, der gør ham betydningsfuld - offer og bøddel er hinandens hjælpere, uden hinanden ville de ikke være noget værd. Det er romanens djævelske pointe.

Ansøgning til hoffet angiver ikke nogen udvej ud af denne elendighed, det kunne man ikke i 1982. Den er derimod udtryk for den groteske fantastik, som Johanna Bohley har karakteriseret som så fremtrædende for Stasi-historierne i DDRs sidste år (Bohley). ${ }^{5}$ Det samme gælder Hans Joachim Schädlichs roman Thallhover fra 1986. Schädlich havde efter kontroverser med Stasi i 1979 fået tilladt udrejse fra DDR, og hans roman om 'den evige spion' Thallhover kunne uhindret udkomme i Forbundsrepublikken. Romanen foregår i øvrigt kun til allersidst i DDR, hvor Schädlich lader sin figurs 120 års tjeneste i forskellige efterretningstjenester slutte i 1953. Romanen har dog stadig den groteske grundtone, hovedpersonen er en blanding af den vandrende jøde og en picaresk helt, uhyggelig og dæmonisk, men også fantastisk og fascinerende. Günter Grass videreførte figuren i samme ånd i sin store genforeningsroman Ein weites Feld (En langere historie) fra 1995 i skikkelse af Hofftaler, hovedpersonens 'evige skygge', og løftede den derved op som en slags prototype på den særlige tyske udgave af spionen.

Det samme kan man sige om Wolfgang Hilbigs Ich (Jeg) fra 1993, der må regnes for en af de mest vellykkede kunstneriske behandlinger af Stasi-temaet. Hilbig skrev bogen i slutningen af 1980'erne, hvor han opholdt sig på et permanent visum i Vesten, og endnu før han kunne kende til omfanget af den spionage $i$ kunstnermiljøet på Prenzlauer Berg i Østberlin, som bogen handler om. Først efter murens fald fandt Hilbig ud af, at den figur, som bogens jeg-figur er blevet sat til at udspionere ("Reader" alias Reiner Schedlinski), selv var spion for Stasi. Spioner der udspionerede spioner: det var den groteske virkelighed, som romanen påstår i virkeligheden var med til at undergrave det østtyske system - simpelthen ved at berøve det modstand. Som jeg'ets føringsofficer, Feuerbach, siger et sted: “... enhver sandhed eksisterer udelukkende i kraft af sin modsætning. Vi ville afskaffe beviset på sandheden hvis vi fik ret og den eneste sandhed virkelig kun var hos os” (64). Også den litteratur, der skrives i det snævre litterære miljø, medvirker gennem sine selvberoende, lukkede tegnsystemer til, at diktaturet med dets rigide overvågning

5 I marts 2010 udsendte Kai Sclüter under medvirken af Günter Grass selv bogen Günter Grass im Visier. Die StasiAkte, Links Verlag, Berlin, der giver en omfattende dokumentation af, at den store tyske forfatter blev systematisk udspioneret af Stasi fra 1961 og til murens fald. Grass understøttede generelt de kritiske DDR-forfattere og hævdede gennem alle årene til stor fortrydelse for Stasi, at der kun fandtes én tysk litteratur. Han var efter murens fald til gengæld som en af de få modstander af sammenlægningen af de to Tysklande. Hans dagbøger fra overgangsårene er også lige udkommet. Alt hvad Grass foretager sig, trækker lange skygger i den tyske historieskrivning. 
imploderer: falder sammen, fordi ingen længere tager det alvorligt. Også Jeg er præget af den optimisme, der prægede Stasi-skildringerne i tysk litteratur omkring murens fald: den før så skræmmende overvågning var forbi, og fortidens dæmoner tog sig komiske og groteske ud. Der var overskud til spøg og skæmt.

Afsløringerne af Stasis virke i de 20 år siden murens fald har dog betragteligt ændret tonen. To eksempler kan vise dette. Få år efter "die Wende" opdagede Hans Joachim Schädlich, at han var blevet udspioneret af sin bror, og han skrev i 1992 i tidsskiftet Kursbuch en kort, smertelig beretning om dette forhold (Schädlich 1992a). Pludselig havde den evige, halvkomiske spion indhentet ham i skikkelse af hans egen bror, og temaet blev påtrængende personligt. Schädlich var også udgiver af en af de første antologier, hvor øst-forfattere berettede om deres forhold til Stasi, og skrev selv heri en ond persiflage af 'sine' to spioner, oven i købet uden at nævne, at den ene var hans bror. Selv den ære tilkom ham ikke (Schädlich 1992b).

I 2009 udsendte hans datter, Susanne Schädlich, imidlertid en beretning om affæren, Immer wieder Dezember (Altid december), hvor stilen er anderledes hård og kontant. Her afdækkes 'gentleman-spionen', Karl-Heinz Schädlich, der elskede kvinder og engelske detektivhistorier, og hans nederdrægtige dobbeltspil i det østtyske litteraturmiljø efter udvisningen af Wolf Biermann i 1976. Især gennemgår Susanne Schädlich hans forsøg på at sabotere familiens muligheder for at få fodfæste i Vesttyskland efter flugten og den systematiske undergravning af faderens psykiske helbred. For Stasi handlede det om at demonstrere, at alle forfattere, der forlod DDR, gik det ilde. Susanne Schädlichs harmdirende og følelsesintense bog - der også er præget af sorg over den højtelskede onkels forrædderi - er blevet en kæmpesucces i Tyskland og har været med til at påvirke de seneste års debat om overvågningssamfundet. Stasi er ikke længere sjov og ballade eller groteske kovnerier på slap line. Hvor temaet i begyndelsen af 1990 var noget, man regnede med tilhørte en svunden tid, man i hastigt tempo skulle lægge bag sig og derfor kunne behandle med historiens ironiske distance, har den aktuelle kontekst givet temaet en fornyet alvor.

Dette er baggrunden for den blandt de unge tyske forfattere, der i særlig grad opsamler denne interesse for overvågning: Juli Zeh. Hos hende løber traditionen fra kampen mod Stasi sammen med den omtalte fornyede følsomhed over for overvågning i det aktuelle Tyskland. Om Zehs enorme succes er et resultat af, at hun er båret frem af denne bølge, eller om hun selv i noget omfang har været med til at skabe den, er selvfølgelig umuligt at afgøre. Formodentlig lidt af begge dele. Zehs baggrund er ikke østtysk: hun er født 1974 som datter af præsidenten for den daværende tyske Bundestag i Bonn og har en jurisisk uddannelse ved vestlige universiteter bag sig, der dog blev afsluttet med en afgangseksamen fra Leipzigs universitet 2003. I Leipzig studerede hun også på den tyske forfatterskole, hvor hun efterfølgende også har været gæstelærer. Hun har altså som en anden af de fremtrædende nyere tyske forfattere, Bernhard Schlink, haft en parallel juridisk og skønlitterær løbebane. 
I sit generalangreb på den tyske overvågningsstat med bogen Angriff auf die Freiheit (Angreb på fribeden) fra 2009, slog hun sig imidlertid sammen med en forfatter, hvis baggrund var direkte østeuropæisk: Ilija Trojanow, født 1965 i Bulgarien og efter familiens flugt til Tyskland (via Jugoslavien) i 1971 tysk statsborger og tyskskrivende forfatter. ${ }^{6}$ Trojanow har også i længere tid boet i udviklingslande, specielt i Afrika, og sammen med Juli Zeh har de to både et jurafagligt-tysk og et østeuropæisk-globalt blik på overvågningsproblematikken og dens fare for det moderne samfund.

Zeh/Trojanow ser demokratiernes reaktion på 9/11 som det store moderne angreb på friheden. Efter 11. september 2001 oparbejder den tyske stat (og andre vestlige stater) en angst $\mathrm{i}$ befolkningen og en katastrofeforventning, der legitimerer alle former for kontrol med indbyggerne selv og med den information, man har til rådighed. Hvor den gamle fjende var "die drüben" (som en vits i DDR sagde: "Für die drüber sind wir drüben"), er det nu de netværk, der unddrager sig en statslig kontrol, der er fjenden. Strækkende sig fra private foreninger og vennekredse over egentlige terrornetværk (Al Quaeda, etc.) til internettet selv, der er "alle netværks moder": "Netværk er det 21. århundredes drager. De er uoverskuelige, ubegrænsede og svære at kontrollere. Og derfor må sikkerhedsmyndighederne til stadighed have stillet flere og flere redskaber til rådighed. Kort og godt: netværk er den perfekte statsfjende.” (Trojanow \& Zeh 124) De to forfatteres gennemgang af hele paletten af forholdsregler til at bekæmpe denne selvskabte statsfjende er detaljeret og uhyggelig. Tyskland er ikke længere en oplyst retsstat, er deres konklusion, men en paranoisk overvågningsstat, hvor politikere, pengefolk og juraprofessorer sidder og trækker i trådene og forsøger at inddæmme det potentielt frigørende $\mathrm{i}$ informationssamfundet.

Og til borgernes store tilfredshed, i alt fald accept. Det mest nederdrægtige (og mest problematiske) i Angreb på fribeden er måske de to forfatteres billede af "Archim Angepasst" ("Torben Tilpasset”), den almindelige tysker, der har lært at elske magthaverne og accepterer alle indskrænkninger i sit privatliv og selvstændighed, fordi han har lært, at det tjener Statens, dvs. hans egen, interesse. "De lykkelige slaver er de mest forbitrede modstandere af friheden”, citerer de Marie von EbnerEschenbach for $i$ et af bogens kapitelmotto'er (119).

Her undervurderer de formodentlig to instanser: dels den Forbundsdomstol, hvis forsvar for retssikkerhed de dog gang på gang - som Per Øhrgaard - fremhæver, men dog ikke anser for tilstrækkelig; dels den folkelige modstand, der i dag hersker i Tyskland mod alle de tiltag, som Zeh og Trojanow beskriver i bogen. En modstand, som jeg skitserede omfanget af i begyndelsen af denne artikel ${ }^{7}$. En modstand, de selv er et strålende eksempel på, og som må være en af forudsætningerne for den

6 I romanen Die Welt ist gross und Rettung lauert überall fra 1996 har han litterært bearbejdet denne historie.

7 Zeh og Trojanows essaysamling er i øvrigt ikke den første af sin art på tysk: allerede i 2001 udsendte Rolf Gössner bogen "BigBrother” Æ Co. Der moderne Überwachungsstaat in der Informationsgesellschaft, Konkret Literatur Verlag, Hamburg. Gössner havde en fortid i borgerretsbevægelsen og havde selv i en årrække været overvåget af det vesttyske Forfatningsbeskyttelseskontor. Han er et af de mange eksempler på kontinuiteten i den tyske kamp mod overvågning og spioneri. 
succes, de begge - især Juli Zeh - har fået som forfattere efter århundredskiftet. Sine litterære kvaliteter ufortalt, der nok ville have sikret hende en position i enhver historisk situation, er Zeh først og fremmest samtidens forfatter: den stemme, der formår at formulere nøjagtig det tema i den form, som store dele af det tyske samfund har brug for lige nu.

Jeg skal her nøjes med at pege på Juli Zehs seneste bog Corpus delicti (med den Kafka-klingende genrebetegnelse "en proces"), der udkom parallelt med debatbogen i 2009 og er på vej på dansk. Kort inde i Angreb på fribeden afbryder de to forfattere fremstillingen "med et vigtigt budskab: Dette er ikke science-fiction. [...] Dette er ikke 1984 i Oceanien, men året 2009 i Forbundsrepublikken” (10). Alligevel er 1984-modellen med overalt i essaysamlingen, og den er det i udpræget grad i Corpus delicti. Diktaturet består her i statens totalt gennemregulerede sundhedssystem, hvor alt tænkes ud fra størst mulig sundhed til borgerne. Og som hos Orwell kæmper en enkeltperson, den unge kvinde Mia, mod det autoritære system, forsøger at trække sig tilbage til privatlivet, men bliver opdaget, torteret, og i en tvetydig slutning kunne det se ud, som om hun - som Orwells hovedperson, Winston Smith, er blevet tvunget til at acceptere systemet. "Metoden”, der også hos Zeh benytter et mærkeligt ny-sprog (avisen hedder "Den sunde menneskeforstand", det mest sete talkshow "Hvad alle tænker", etc.), har vundet. Det forbliver dog mere åbent end hos George Orwell.

Handlingen foregår i midten af det 21. århundrede - uden at man altså skal tro, at det er science fiction. Det handler om Forbundsrepublikken (og den øvrige udviklede verden). Usund opførsel er forbudt, og modstand mod sundhedsforskrifterne bliver straffet med nedfrysning på ubestemt tid. Det er det, Mia kæmper imod, ansporet af sin afdøde broder, der tog sit eget liv efter en falsk anklage. Mia er alene og vil ikke tilslutte sig gruppen R.A.K. (som ikke er Rote Armé Fraktion, men "Recht Auf Krankheit" (ret til sygdom), ligheden er dog iøjnefaldende) eller andre kamporganisationer. Under processen mod hende får hun smuglet en nål ind i fængslet, hvormed hun graver den chip, som alle indbyggere har fået indopereret i armen, ud, og får derved fysisk befriet sig fra overvågningssamfundets greb. I den store retssag mod hende (og Juli Zehs bøger slutter ofte med sådanne spektakulære retssager) falder alle systemets repræsentanter da også moralsk sammen, og hun står tilbage med noget, der ligner et martyrskær. Selv om det udtrykkeligt bliver nævnt, at hun hverken er Jesus af Nazareth eller Jeanne d'Arc (263). Dette er ikke myte, kunne man tilføje, men Forbundsrepublikken anno 2009. Ved at lægge handlingen frem til midten af det 21. århundrede, angiver Zeh det eneste mulige våben mod martyrerne: rå vold. Corpus delicti er en skræmmende bog.

Sundhedsdiktaturet, hvor alle fysiske aktiviteter skal registreres og indberettes, betjener sig selvfølgelig også af et udbredt net af spioner ("orme”), og aflytninger, brevåbning og konstruktion af forskellige falske anklager er hverdag. Det er åbenbart, at også Stasi-modellen stadig fungerer i Corpus delicti, her ikke lagt tilbage i barokken som hos Joachim Walther, men ud i fremtiden. Skal Juli Zeh danne sig et billede af det rigide overvågningssamfund, har hun forbillederne lige ved hånden. 
"Metoden" er den marxistisk-leninistiske ideologi, der jo også anså sig for den rene, humane fornuft. I et stort manifest, som man godt kan kalde anti-kommunistisk, bekender Mia sig til retten til 'ufornuft', retten til at tage fejl og handle ud fra følelser i stedet for kalkulation. Det er et individualistisk og sentimentalt program, der har et strejf af den Rousseau, som et sted i forbifarten bliver næunt som en af inspirationerne: "Jeg trækker min tillid til en retsinstans tilbage, der kan takke sin succes den fuldstændige kontrol af sine borgere. Jeg trækker min tillid til et folk tilbage, der tror, at total gennemlysning kun skader den, der har noget at skjule” (186). Det er Luther foran domstolen i Worms, der bekender, at han kan ikke andet - Gud hjælpe ham. Og det er den store tyske oplysningstraditions patos, en patos, som også George Orwell benyttede sig af i 1984 for at advare England mod en totalitarisme, man havde set så forfærdende resultater af.

Det er dog vigtigt at læse Corpus delicti parallelt med Angreb på fribeden som det følelsesintense udtryk for essay-bogens kølige og informative analyse. Dybest set er de to bøger sider af det samme projekt, ligesom Zeh i sine foregående bøger har kombineret det intimt-gribende med den videnskablige diskurs: i Schilf (Det sidste spørgsmål), 2007 en familietragedie med naturvidenskabens totaliserende hegemoni: også et aspekt af overvågningstemaet; og i mesterværket Spieltrieb (Legesyge), 2006 diskuteres forholdet mellem en terrorgruppe, der er opstået i en tysk gymnasieklasse, og det retssystem, der skal dømme den. Juli Zeh er en forfatter, der stiller modsætningerne skarpt og principielt op, det er hendes styrke i den nye tyske litteraturs landskab.

Måske også hendes svaghed, fordi hendes bøger bliver forudsigelige og kan hælde til moralsk patos. Den bevægelse, hun er en del af, dementerer faktisk den pessimisme, hendes bøger forfægter. Dertil kommer, at bagsiden af den etiske forpligtethed, som Juli Zeh kan have med fra arven fra DDR-litteratur ofte, som Alexander Cammann gjorde opmærksom på i Die Zeit i november 2009, bevirker en dyrkelse af borgerlig individualisme og traditionel følsomhed. Både Juli Zeh og Susanne Schädlich kan forfalde til begge dele, for nu at nævne de to i denne sammenhæng behandlede forfattere. Men i temaet overvågning har de spillet sammen $i$ et forsvar for borgerrettigheder, der i Tyskland som andre steder i verden er under angreb i disse år. "Privatlivets fred" hedder vor tids slagmark.

I den kamp trækker forfattere som Juli Zeh og Susanne Schädlich både på traditioner fra DDR-litteraturen i almindelighed og fra opgøret med Stasi i særdeleshed. Tyskland har erfaringer med diktatur og dets forskellige mekanismer tættere inde på nutiden end mange andre demokratiske stater. Derfor er følsomheden over for reaktivering af disse mekanismer også større i Tyskland end andre steder. Her har tyskerne og den tyske litteratur noget at lære den øvrige verden, vil jeg hævde. Kampen mod overvågning foregår i vort store naboland på tyske præmisser og med de forestillinger, den tyske historie giver. Men kampen har et globalt perspektiv. 


\section{LITTERATURLISTE}

Johanna Bohley. "Hoftaller, Uhltzscht und andere Helden. Konfigurationen des Komischen in der Nachwendeliteratur." Die Stasi in der deutschen Literatur. Red. Franz Huberth. Tübingen: Attempto, 2003. 157-74.

Cammann, Alexander. "Im Osten ging die Sonne auf." Die Zeit 9/11 2009: 5-15.

Gössner, Rolf. 'BigBrother' హ Co. Der moderne Überwachungsstaat in der Informationsgesellschaft, Konkret Literatur Verlag, Hamburg, 2001.

Hilbig, Wolfgang. Jeg [Ich, 1993]. København: Tiderne Skifter, 2002.

Huberth, Franz. "Die Stasi in der deutschen Literatur". Die Stasi in der deutschen Literatur. Red. Franz Huberth. Tübingen: Attempto 2003: 11-31.

Huberth, Franz. Aufklärung zwischen den Zeilen. Stasi als Thema in der Literatur. Köln: Böhlau Verlag, 2003.

Schädlich, Hans Joachim. "Die Sache mit B.” Kursbuch 109 (1992): 81-91.

Schädlich, Hans Joachim. "Jeder ist klug, der eine vorher, der andere nachher." Aktenkundig. Red. Schädlich. Rowohlt: Berlin, 1992: 166-75.

Sclüter, Kai. Günter Grass im Visier. Die Stasi-Akte. Berlin: Links Verlag, 2010.

Trojanow, Ilija \& Juli Zeh. Angriff anf die Freiheit. Sicherheitswahn, Überwachungsstaat und der Abbau bürgerlicher Rechte. München: Hanser Verlag, 2009.

Øhrgaard, Per. Tyskland - Europas hjerte. København: Gyldendal, 2009.

Zeh, Juli. Corpus delicti. Frankfurt/M: Schöffling \& Co., 2009. 